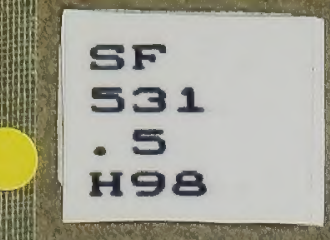

(1)

(35)

xar. 


\section{Cornell University Library}

The races of honey bees and their charac 


\title{
THE RACES OF HONEY BEES AND THEIR CHIR.ICTERISTICS
}

\author{
Ray Hutson, B.Sc.
}

\section{Issistant Entomologist, New Jersey Agricultural Experiment Station}

Each race of honey bee has arisen in response to the working of the same natural laws that have given races of every living thing. Isolation by natural barriers, mountains, seas and deserts by forcing in and in breeding and natural selection is the predominating cilusal agent in the origin of races. Such natural segregation gave rise to the different kinds of cattle in different parts of the world, to quote a familiar example. In the last few thousand years man has speeded up nature to produce domestic cattle from wild cattle.

The definitions of races and of characteristics are pretty thoroughly tangled up. A characteristic is a trait or a structure peculiar to a group of individuals. A group possessing certain characteristics is called a race.

The origin of the races of honey bees can be traced in the same way as the origin of races of every animal. Wherever a given race of honey bees is at home we find, on investigation, that its home is set apart by impassible natural obsacles. This, of course, is true only of the region to which it is indigenous and disregards man as a factor in its dissemination. The nature of bees and their habits are practically the same as they were thousands of years ago and it is only within the past few hundred years that man has learned to transport them to any distance.

The different races of bees are the Italians, Caucasians, Carniolans, Germans, Cyprians, Syrians, Holy Land, Saharian and Chinese. These races which are kept by man can all be located as having originated in some region set apart from the rest of the world by mountains, seas, or deserts.

\section{The Italian Bee}

Italy, the home of the Italian bee. is set apart from the rest of Europe by the Alps and is almost surrounded by the sea. The bees which were brought to that country thousands of years ago have been kept in that locality all the time. Their yellow bands, comparative gentleness, house cleaning ability and comparatively great disease resistance have been built up and fixed by the principles of the survival of the fittest as gauged by Italian conditions. The poor cappings attributed to this race have been fostered in the same way by the Italian climate as has their comparative freedom from burr and brace combs and the carrying in of large quantities of propolis. Latterly, since importation to America, the Italian has been modified by dilutions of alien blood and undue attention to the single characteristic of color. This last feature is a very good example of how man can speed up natural processes in the development of a race by selection and hybridization.

\section{The Caucasian Bron}

The Caucasian bees originated in a region bounded on all sides by barriers which the bees witnin the enclosed region were unable to pass; sea on two sides, mountains on one side and desert on the other. 
Bees in this region vary somewhat in color and characteristics. Gorbachoff, the leading authority on Caucasian bees recognizes five races. The Russian investigator. Mikhailoff recognizes but two. In any case the bees vary in color from yellowish to almost black. The variety is called the gray banded Caucasian is recognized by Gorbachoff to be a comparatively mild swarmer, builds few burr and brace combs, caps its honey well and does not build a propolis defense at the entrance. Individuals of this extremely gentle race have a brownish black body color and silver gray bands of hair on the abdorren. The queens are comparatively large when compared with the Italians, are a Jark mahogany color with lighter regions near the articulations of body segments. The drones are blue-black. The workers are not rery different in size from the Italians. The Caucasian bee will rob though not as enthusiastically as the Italian nor as persistently as the German. The production of honey by this bee is rery satisfactory when compared to the Italians. The Caucasian bees are noted for seeking their own homes. That is, with a colony of Caucasians in a yard of Italians it will be a rare occurance to find stray Caucasian bees in an Itlian hive. Caucasians winter well due to a very compact winter cluster.

\section{The Calniolan Bee}

As in the case of the other races the Carniolan bee is native to an isolated region. This is located high in the Alps Mountains. There are undoubtedly strains of these bees. Prof. Francis Jaeger is one of the authorities for this assertion although it has not been worked out as thoroughly as in the case of the two races hitherto mentioned. The Carniolan bee, it seems, is slightly larger than the Italians and Caucasians. It is very gentle and prolific. It is a good honey gatherer, and a fine cell builder for use in a clueen rearing yard. They collect little propolis, winter admirably and cap their honey white. The consensus of opinin among people who have tried them is that they swarm excessively. In regard to the different races of Carniolan bees it appears that the Banats, Dalmatian and other bees resembling the Carniolans are hybrids of the true Carniolan race with other bees and derive the names given them from the province in which they originated.

\section{The German Bee}

The German bees are black in color and are known among American beekeepers as black bees. These bees are subject to rery great rariation which is partially explained by the hybridization with other races, chiefly the Italians. The German bee is no exception of the rule that races of bees were originated in distinct regions. It is probable that the true German bee arose in the reigon roughly outlined by the present German Republic. It is very doubtful whether at present there are Jure German bees in the United Stites. German bees are reputedly less prolific than Italians, build more queen cells, develop fertile workers more readily, are poor housekeepers, are nervous and succumb more quickiv to European foulbrood. Many beekeepers, howerer, defend the hlack bers hecause of their habit of capping honey more at actively than 
Italians. As pointed out before it is very doubtful whether there are pure German bees found anywhere in the United States. In this case the characteristic for capping the comb honey white must be a very deep seated one. The German race of bees was the first one introduced into the United States and at one time was the only race found here. It has been since 1860 that the hybridization, chiefly with Italians has taken place.

\section{The Cyprian Bee}

The Cyprian bee is very yellow and its abdomen is pointed. The queens are prolific and somewhat smaller than the Italians. They cap honey with very little air beneath the cappings which gives it a watery appearance. They swarm a great deal and this, together with their very unmanageable qualities and irritable nature, has caused their abnandonment by American beekeepers after a rather thorough trial. Latterly, there $\mathrm{hs}$ been some interest in Cvprian bees because of their reputed prolificacy and the possibility of modifying their temper through certain ultra-violet radiations. Mr. Clifford Muth of Cincinnatti has been foremost in these trials.

\section{The Syrian Bee}

The Syrian bees are noted for swarming, large numbers of queen cells and poor wintering. These bees were introduced in 1880 by Jones and Benton but were abandoned as valueless because of these habits and their poor wintering qualities.

\section{The Holy Land Bee}

The Holy Land bees are probably a suecial race of the Syrians.

\section{The Egyptian Bee}

The Egyptian bees are somewhat smaller than the race known to the American beekeepers. They are yellow in color and the abdomen is covered with grayish white hairs. According to von Buttel-Reepen they do not form a winter cluster and cannot withstand cold weather. The cappings are very watery.

\section{The Saharian Bee}

The Saharian bees are found in the region between the Atlas Mountains and the Sahara Desert in North Africa. They were brought from that country to France by Baldensperger and were exhibited by him at Quebec in 1924. They differ from the Italian bee in having orange colored segments on the abdomen. Unfortunately Baldensperger was unable to preserve the race in its vurity.

\section{The Tunisian Bee}

The Tunisian bee is black. It is sometimes called Punic and came from North Africa. These bees are extremely cross, propolize excessively and winter badly. There are certain other races of bees in Africa which have not as yet been domesticated. 


\section{The Chinese Bee}

Chinese pees are smaller than the Italians and are inclined to bite rather than sting. They have a heavy coat of long gray hair. It is listed as an undesirable race by people who have had experience with Italians.

\section{Other Races of Bees}

In various parts of the world where continuous isolation is obtained other races of bees have arisen. There are at least three races in India. The Giant bee, which is, as its name indicates, a much larger bee than the bees to which we are accustomed. There is also a race slightly smaller than Italians and a very small race. These bees all build single combs and no great effort has been made to keep them in in hives as they do not seem to hold any great promise of worth.

Tarlton-Rayment has recently described another race of wild bees from Australia, which is an isolated continent. These bees build small combs in various locations and do not hold any great promise of profit.

There are also the so-called stingless bees of Mexico, Central and South America. These stingless bees belong to the Genera Melipona and Trigona and, as their name indicates, do not have a stinger. The do bite and have a habit of buzzing excitedly when disturbed. They store comparatively small amounts of an inferior honey in grape-like masses of wax cells. They are kept only to a slight extent by the natives in hollow logs suspended on the verandas of their houses or from trees nearby to protect them from depredation by lizards their chief enemy in that climate.

It would seem from this brief survey of the races of bees that there are but one or two races of bees besides the race with which we are familiar which hold any great promise of being useful in this country. $\mathrm{It}$ is probable that the Italian bee is superior under most conditions. However. if the same amount of care in selection and breeding had been expended upon the German bee it doubtless would also have developed into a very superior race when compared with the present German bees. The Caucasian and Carniolan bees have certain obvious advantages over the Italians while they also have certain evident disadvantages. There has been more care expended in breeding Carniolans and Caucasians in this country than in the case of the Germans, so it would appear that possibly the use of the Caucasians or Carniolan bees might in certain cases result in profit. However, if it is ever possible to again import German bees from Switzerland or some of the places where care and time has been expended on breeding them, we would doubtless find that these bees wre as much superior to the old Germans as the Italians. In any case it would be well to supplant Italians very gradually by another lace hecause we know pretty well what the characteristics of the Italian bees are under our conditions and we do not always know what will happen with newer races. 


\section{Cornell University Library}

The original of this book is in the Cornell University Library.

There are no known copyright restrictions in the United States on the use of the text.

http://www.archive.org/details/cu31924003450867 


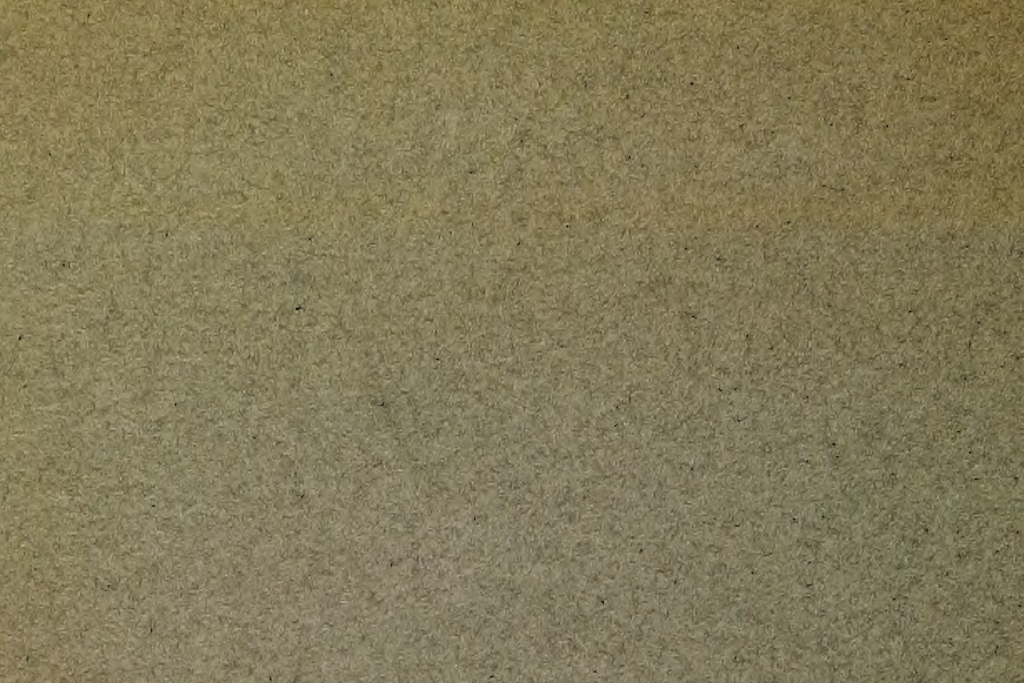

